\title{
SOUND PATTERN OF INDONESIAN PLOSIVES
}

\author{
Huili Li $^{l} \quad$ I. Praptomo Baryadi ${ }^{2} \quad$ I Dewa Putu Wijana ${ }^{2 *}$ \\ Yuxi Normal University ${ }^{1}$, Universitas Gadjah Mada ${ }^{1,2}$ \\ unalhl@hotmail.com ${ }^{1}$
}

\begin{abstract}
As a language which is quite extensively used, Indonesian segments are already known by linguists. Although experimental research methodology is relatively new, it is useful for undertaking further research on Indonesian phonology and phonetics. It can assist in generating phonological and phonetic data as evidence of sounds within a theoretical framework. Sound pattern study by means of experimentation is selected as the theoretical framework for this research. As sound patterns of one language consist of many subparts, this research only focuses on the Indonesian plosive sound pattern. This paper examines sound pattern of Indonesian plosives and their special features. In order to do this research, a quantitative method is adopted for data collection and analysis. Indonesian words with plosives at the beginning of the second syllable and first syllable are respectively designed as stimuli for recordings. Then sound analysis software Praat is applied to measure gap and the voice onset time of plosives as parameters of data. The result of this research shows that the Indonesian plosive sound pattern forms two clear clusters on an acoustic plosive chart. Voiceless plosives have a longer gap duration than their corresponding voiced plosives. Front plosives in the vocal cavity have a longer gap than back plosives, but are shorter in VOT length. Such acoustic results will provide the basis for further research such as auditory phonetics experimental research and second language acquisition. Additionally, the visualization of abstract concepts, compared to the Chinese sound pattern, will help Indonesian learners from China to understand the Indonesian sound pattern better and Indonesian language teachers to seek better solution to students' pronunciation problems.
\end{abstract}

Keywords: Indonesian language plosives, sound pattern, experimental research

\begin{abstract}
Abstrak
Bahasa Indonesia telah digunakan secara luas dan segmen-segmen telah dipahami oleh para linguis. Walaupun terbilang baru, metode penelitian eksperimental dapat digunakan untuk melakukan penelitian mendalam, terutama dalam bidang fonologi dan fonetik bahasa Indonesia. Metode ini dapat membantu menghasilkan data fonologis dan fonetik sebagai bukti bunyi bahasa dalam kerangka teoretis. Studi pola bunyi bahasa dengan cara eksperimen dipilih sebagai kerangka teoretis dalam penelitian ini. Pola bunyi suatu bahasa terdiri atas banyak subbagian, tetapi penelitian ini hanya berfokus pada pola bunyi plosive bahasa Indonesia. Makalah ini mengungkapkan pola bunyi plosif bahasa Indonesia dan fitur-fitur khususnya. Penelitian yang dilakukan ini mengadopsi metode kuantitatif untuk mengumpulkan dan menganalisis data. Kata-kata bahasa Indonesia dengan plosif pada awal suku kata kedua dan suku kata pertama, masing-masing dirancang sebagai stimulus untuk direkam. Perangkat lunak analisis suara "Praat" digunakan untuk mengukur gap (celah) dan waktu mulai suara (voice onset time) dari plosif sebagai parameter data. Hasil penelitian ini menunjukkan bahwa pola bunyi plosif bahasa Indonesia membentuk dua kelompok pada bagan plosif akustik. Bunyi plosif tidak bersuara memiliki durasi gap lebih panjang daripada bunyi plosif bersuara. Bunyi-bunyi plosif yang diucapkan di depan rongga mulut mempunyai
\end{abstract}


gap lebih panjang daripada bunyi-bunyi posif belakang, tetapi waktu mulai suara lebih pendek. Hasil akustik ini merupakan dasar untuk penelitian selanjutnya, misalnya, penelitian fonetik auditoris dan pemerolehan bahasa kedua. Ditambah lagi, perbandingan pola bunyi bahasa Indonesia dengan pola bunyi bahasa Mandarin dengan visualisasi konsep abstrak dapat membantu para pelajar yang berasal dari China maupun para pengajar bahasa Indonesia untuk mendalami pengertian bunyi kategori plosif dan membantu mencari solusi yang lebih baik untuk mengatasi masalah pengucapan kata.

Kata Kunci: bunyi plosif bahasa Indonesia, pola bunyi, penelitian eksperimental

\section{INTRODUCTION}

Every language has its own phonological system, and each system forms its own sound patterns. Only when speakers of the language articulate sounds correctly or in certain ways can listeners perceive speech sounds and understand what speakers are saying.

A key concept underpinning this research is the concept of a sound pattern. Different scholars have given different definitions and applied different approaches to study the sound pattern. In Chomsky and Halle's monumental work The Sound Pattern of English (Chomsky \& Halle, 1968), sound structure is described as having phonetically distinctive features. A lot of technical terms are utilized, together with very abstract phonological process representation, which make the sound pattern of one language less easily understood by non-linguists. Meanwhile, it is conceivable at the time when Chomsky and Halle's book was written, technologies that were available for phonology study, in particular for phonetics, were very limited. Later, with the development of experimental facilities, more technical means and techniques began to become available in phonological research. This gave rise to experimental phonology and experimental phonetics.

The primary purpose of experimentation is not to create knowledge, rather, it is a way of refining our knowledge (Ohala \& Jaeger, 1986). As a well-known language, Indonesian segment inventory and phonological processes as well as phonotactic constraints have already been studied by many scholars in Indonesia using conventional methods. Among them, Lapoliwa (1981) adopted generative phonology method developed by Chomsky and Halle to describe Indonesian Phonology. Chaer (2009) and Muslich (2008) also contributed to the description of Indonesian phonology. However, none of these works used experimental method for phonological studies. In exploring why people who do not speak exactly the same language are still mutually intelligible, Professor Shi Feng $(2013$; 2008) from Nankai University proposes "sound pattern" as the frame of sounds of any languages. According to his theory, besides acoustic sound pattern, there should be auditory and physiological sound patterns, too. Within this sound frame, expressions in a certain language should be able to be perceived and comprehended. Looking for this sound frame by means of acoustics is a basic step for further studies such as speech perception and articulation. Acoustic data will be collected to provide phonetic evidence and the findings can be visualized based on the processed data.

The acoustic sound pattern study of Shi Feng (2008) based on Chinese consists of four parts. They are sound pattern of tones, sound pattern of vowels, sound pattern of consonants, and sound pattern of intonation. Consonants, unlike vowels, have complex ways of articulation and different places of articulation. Therefore, sound patterns of consonants are further 
subdivided into several sets according to their different features such as plosive sound pattern, fricative sound pattern and nasality. This research adopts the theory of sound pattern as its framework. Experimental methods developed from such a systematic linguistic theory are still new. In the past few years they were mainly applied in researching Mandarin Chinese and Chinese dialects. A literature review shows such methods have not been utilized in Indonesian phonological study.

Indonesian plosives are very different from Chinese plosives. Many Chinese students who are learning Indonesian usually experience great difficulties in differentiating between Indonesian voiced and voiceless plosives in both listening and speaking. This is because Indonesian plosives have voice contrast, while Mandarin Chinese plosives have aspiration contrast. That is to say, Chinese does not have the sounds [b], [d], and [g]. Besides, palatal plosives [c] and [J] do not exist in Chinese either. In China, except for some conventional phonological study on Indonesian language, for example, Liang Yijia's (2014) thesis on comparing segment inventories of Mandarin Chinese and Indonesian phonemically, experimental study on Indonesian phonetics and phonology is still unexplored. This research fills a need to expand knowledge on Indonesian language phonetics for Indonesian language learners with Chinese as their mother tongue.

This research is designed to re-examine Indonesian plosives by means of experimentation. Phonetic data will be collected acoustically and the results will be presented not only by acoustic numeric data but also pictorially.

\section{METHOD}

\section{Informants}

The Javanese language has a big influence on the Indonesian language in many ways. The total number of Indonesian speakers with a Javanese language background accounts for the largest proportion of Indonesian speakers. In order to control this variable, we chose ten informants who are Indonesian speakers from East Java, Central Java and Yogyakarta with Javanese language as their mother tongue, since Indonesian is very commonly spoken as a second and official language in Indonesia. These informants consisted of five female and five male undergraduate students with a similar age of around 20 years old from the Indonesian Language and Literature Department, Gadjah Mada University.

As data was collected, new problems appeared. It proved difficult to measure the VOT of Indonesian voiced plosives in spectrograms of plosives from these Indonesian speakers with Javanese background. Then the experiment had to be tried again with informants from nonJavanese backgrounds. Then more informants from many islands outside Java studying in Gadjah Mada University were recruited to supplement existing data.

\section{Stimuli}

Standard Indonesian includes 4 pairs of plosive consonants [k][g], [p][b], [t][d], and [c][f]. They are contrasted by voice. The first three pairs may appear in the onset of a syllable and also the coda of a syllable with different ways of articulation. The onset and coda plosives form complementary distribution phonetically, because plosives in the position of coda are always 
unreleased, but in the onset position they are always released. The last pair, [c[[J], only occur in the position of syllabic onset, not in the position of coda.

Gap is the duration of time after the previous sound and before the release of airstream for the plosive sound. For measuring the gap, if plosives in words for recording appear in the beginning of the first syllable, it would be impossible to look for the duration period of closure or gap, hence it is better to use the onset of the second syllable in words. Therefore, words that meet the above condition are selected as stimuli for measuring the gap (see Table 1). As the research progressed, it was found that syllable-initial plosives in the second syllable caused difficulties for measuring VOT, because the first formant of the previous vowel usually disturbs the observation of the plosive VOT. Accordingly, another group of stimuli (see Table 2) was designed for VOT measurement. In order to acquire enough quality data for acoustic phonetic research, all plosives are placed in three different words and each word is read three times in recording. Therefore, the total number of stimuli for each plosive is $1 * 3 * 3 * 10=90$. Recordings with a clear spike and voice bar on the spectrogram are chosen for data collection of gap and VOT.

Table 1. List of words for measuring GAP of Indonesian plosives

\begin{tabular}{llll}
\hline $\mathrm{p}$ & kipas & sepi & kapur \\
\hline $\mathrm{b}$ & mabuk & cabang & gabung \\
\hline $\mathrm{T}$ & kutu & cita & soto \\
\hline $\mathrm{d}$ & sedih & sedap & sudut \\
\hline $\mathrm{k}$ & suku & suka & kaki \\
\hline $\mathrm{g}$ & saga & daging & bagus \\
\hline $\mathrm{c}$ & cicak & suci & cucu \\
\hline $\mathrm{J}$ & najis & kejut & kerja \\
\hline
\end{tabular}

Table 2. List of words for measuring VOT of Indonesian plosives

\begin{tabular}{llll}
\hline $\mathrm{p}$ & pas & pena & puji \\
\hline $\mathrm{b}$ & batu & besi & biasa \\
\hline $\mathrm{t}$ & tas & tes & took \\
\hline $\mathrm{d}$ & dan & desa & dinas \\
\hline $\mathrm{k}$ & kita & kaki & kukus \\
\hline $\mathrm{g}$ & gula & gas & gila \\
\hline $\mathrm{c}$ & cita & cacing & cucu \\
\hline $\mathrm{J}$ & juta & jas & jenis \\
\hline
\end{tabular}

\section{Experiment Facilities}

In this research, hardware facilities such as a computer, sound card and microphone were used to record citation speech of the designed stimuli. Software like Audacity was used for sound recording and Praat was used for sound file analysis. Finally, all data collected was processed statistically with Excel.

\section{ANALYSIS}

Indonesian plosives distributed both in the onset of the syllable and also in the coda of the syllable such as in the words kapuk, dialog; sudut, abad; sedap and nasib. One pair of plosives /c/ and / $/$ / are exceptional since they mostly only fill the onset of a syllable such as in words catat and jahat. The only word with $/ \mathrm{j} /$ in the position of the coda is hijriah adapted from Arabic. Usually plosives at the end of the words kapuk, sudut and sedap are voiceless, and not released. Voiced plosive consonants located at the end of a syllable are not released either, but if we listen carefully to the plosives at the end of the words dialog, abad and nasib, the so-called voiced consonants /b, d, g/ actually have very little voicing. When we say nasib, our lips are not opened for the final consonant. Therefore, Indonesian plosives at the position of the coda of a syllable are not fully voiced throughout the closure. 
There is a clear distinction in meaning between the words such as salip and salib, selat and selad. In these pairs, the vowel is much shorter before the voiceless consonants /p, $t /$ than before $/ b, d /$. In the spectrograms in Figures 1 and 2, we can see the difference in length. The major difference between such pairs of words is in the vowel length, not in the voicing of the final consonants. Additionally, the length of the final voiceless stop consonant is relatively longer than that of the corresponding voiced one after the same vowel. In a narrow transcription, unreleased consonants can be symbolized as [salip $\urcorner$ ], [salib $\urcorner$ ], [selat $\urcorner$ ], [salad $\urcorner$ ]. The small raised mark [ ${ }^{\urcorner}$] stands for no audible release. In this case, plosives at the end of these words are all unreleased. However, the pairs above are not common in the Indonesian language. Words with voiced sounds [b], [d], and [g] at the syllabic final position originate mostly from Arabic language, and a few from Javanese and English. In the bottom stratum of Indonesian-Malay, /p, t, k/ are more active when appearing at the end of a closed syllabic structure such as in words enak, sedap, and mulut than their voiced counterparts. While /p, t, $\mathrm{k}, \mathrm{c} /$ often contrast with /b, d, g, J/ at the position of syllable onset. For example, /t/ contrasts /d/ in words tua and dua, /k/ /g/ in kelap and gelap, /b//p/ in baku and paku, /c/ / / $/$ in baca and baja.

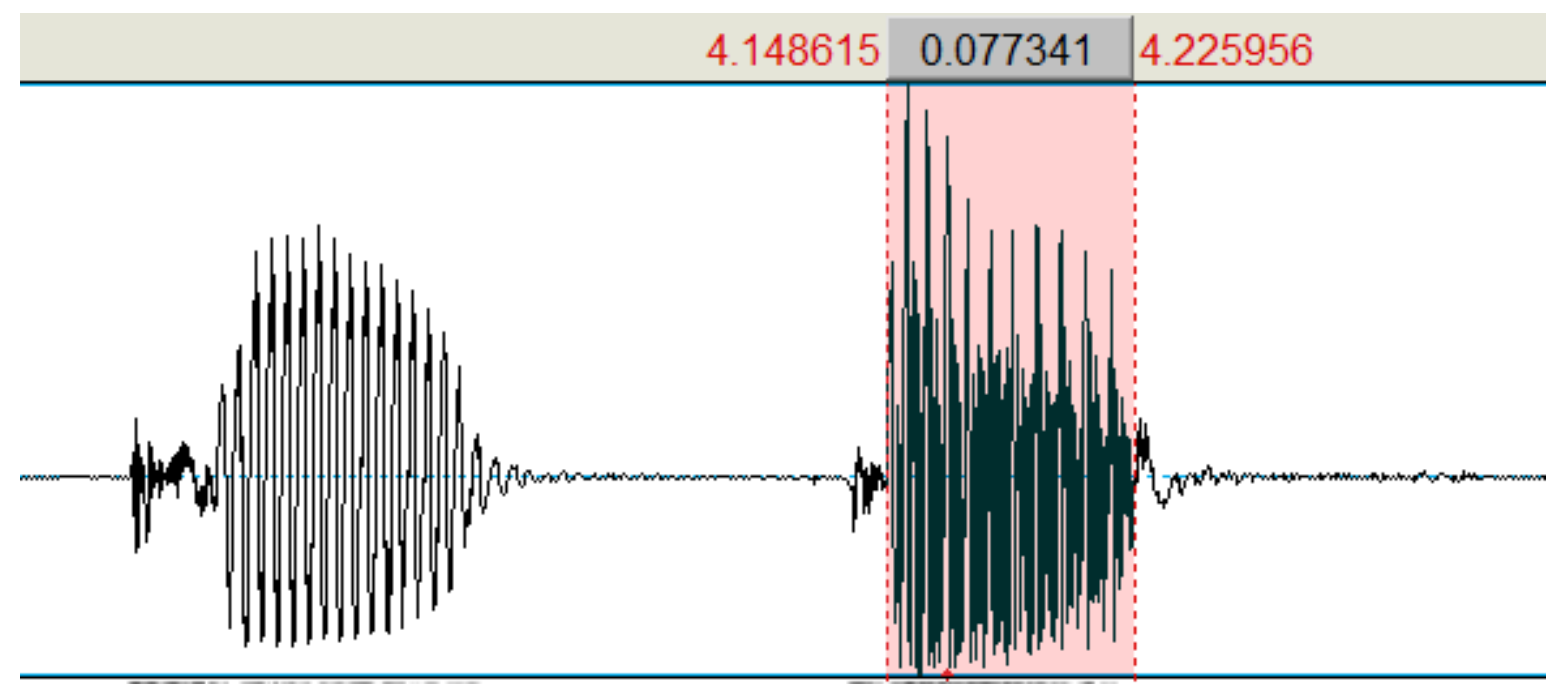

Figure 1. Acoustic waveform in "kitap"

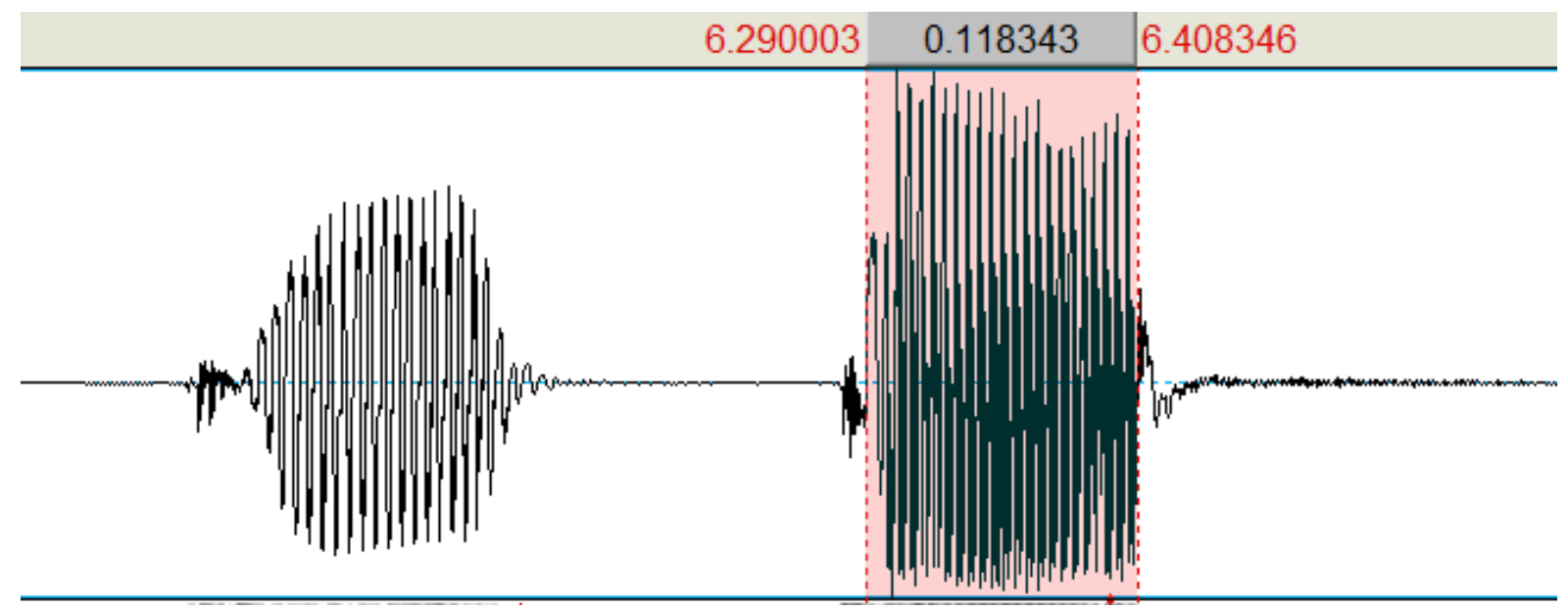

Figure 2. Acoustic waveform in "kitab"

Words like kitap and kitab with contrast at plosives of syllable coda are actually not common in Indonesian vocabulary. Those that originally derive from Malay mostly do not end with voiced 
plosive consonants. For example, murid, ajaib ending with $[\mathrm{d}, \mathrm{b}]$ are loanwords from Arabic, meanwhile words with [g] are much fewer. For instance, the word gudeg is adapted from Javanese, and dialog from English. Paired contrast between voiced and voiceless plosives at the end of a syllable rarely occurs so that they can be ignored.

However, words such as ayak, ayap and ayat are all distinguishable, although their final consonants are unreleased. The difference in the sounds is in the way that the vowels end. The consonants before and after a vowel always affect it, so there is a slight but noticeable difference in its quality. The consonant gestures are superimposed on the vowel in such a way that their effect is audible throughout much of the syllable (Ladefoged \& Johnson, 2006).

A plosive is a stop made with a pulmonic airstream mechanism. Therefore, in the conduct of Indonesian plosive sound pattern research, acoustic parameters of gap and VOT are employed as parameters for examining plosive sound patterns (Shi, 2012). In Table 3 is data on the mean values of Indonesian plosive VOT and the gap collected from the second group of ten informants. Figure 3 is the statistical scatter chart based on the mean values of VOT and gap to visualize the pattern of Indonesian plosives.

Table 3: Mean value of Indonesian plosive VOT and gap

\begin{tabular}{ccccccc}
\hline Plosives & VOT & $\begin{array}{c}\text { Number of } \\
\text { samples }\end{array}$ & $\begin{array}{c}\text { Standard } \\
\text { derivation }\end{array}$ & gap & $\begin{array}{c}\text { Number of } \\
\text { samples }\end{array}$ & $\begin{array}{c}\text { Standard } \\
\text { derivation }\end{array}$ \\
\hline$[\mathrm{p}]$ & 10 & 75 & 5 & 155 & 76 & 53 \\
\hline$[\mathrm{b}]$ & -76 & 82 & 30 & 96 & 80 & 22 \\
\hline$[\mathrm{t}]$ & 9 & 79 & 4 & 137 & 79 & 39 \\
\hline$[\mathrm{d}]$ & -82 & 79 & 37 & 94 & 80 & 41 \\
\hline$[\mathrm{c}]$ & 48 & 74 & 19 & 108 & 70 & 44 \\
\hline$[\mathrm{J}]$ & -84 & 57 & 42 & 90 & 65 & 34 \\
\hline$[\mathrm{k}]$ & 30 & 77 & 12 & 133 & 70 & 43 \\
\hline$[\mathrm{g}]$ & -87 & 72 & 46 & 101 & 74 & 33 \\
\hline
\end{tabular}

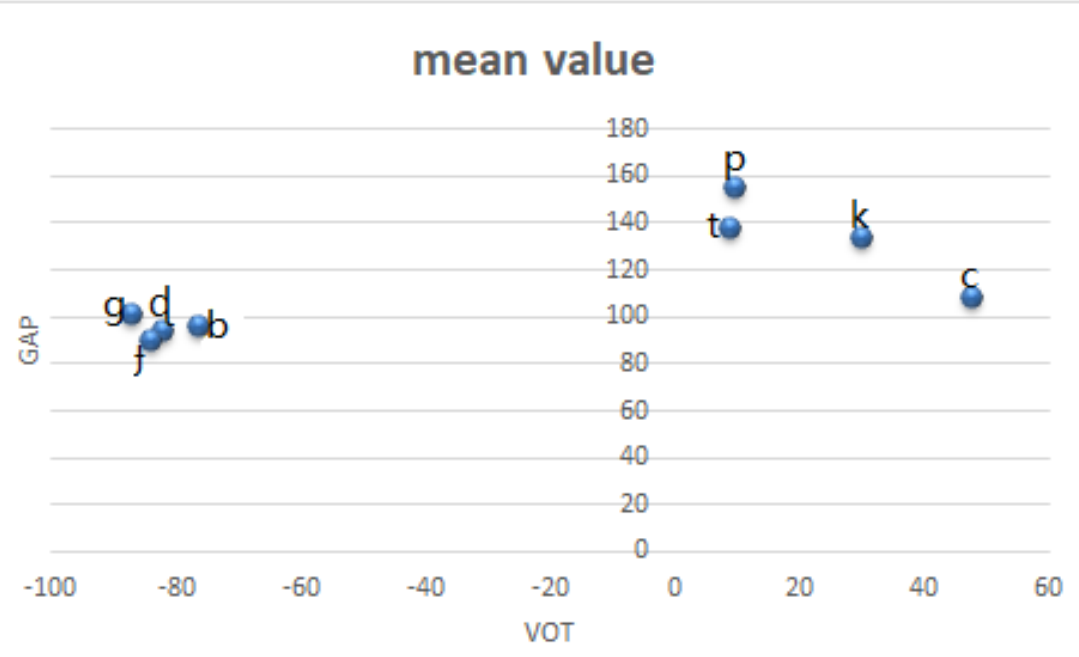

Figure 3. Sound pattern of Indonesian plosives

In Table 3, all mean values of the data are represented in a two-dimensional coordinate. VOT is on the horizontal axis, and the gap is on the vertical axis. The scale of the gap is $0 \sim 180 \mathrm{~ms}$. VOT of voiced plosives is negative. VOT of voiceless unaspirated plosives is near zero. Therefore, VOT is 
distributed on both sides of the vertical axis. Voiced and voiceless plosives form two clusters of sound pattern on both sides of the y-axis.

\section{Gap}

Gap is the time duration of closure before airstream is released in articulation of plosives. The value of gap demonstrates the "stop" feature of plosives and reflects the degree of muscle tension when articulating. Its performance on the spectrogram is the gap from the end of the vowel periods to the beginning of the spike that shows the removal of closure. Due to the fact that the gap on the spectrogram makes no distinction from the blank before any consonant, gap is better measured on the plosive that is placed in the onset of the second syllable of a word.

The gap averages, based on analysis of collected data, are [p]155ms [b]96ms, [t]137ms [d] $94 \mathrm{~ms},[\mathrm{c}] 108 \mathrm{~ms}[\mathrm{f}] 90 \mathrm{~ms},[\mathrm{k}] 133 \mathrm{~ms}$, and $[\mathrm{g}] 101 \mathrm{~ms}$. The unit of measure used is millisecond (ms). In these four pairs of voiceless and voiced plosives, voiced plosives generally have a shorter gap duration than their corresponding voiceless plosives, for example gap[p]-gap[b] is $59 \mathrm{~ms}$. gap[t]-gap[d] is $43 \mathrm{~ms}$. Gap[c]-gap[f] is $18 \mathrm{~ms}$. Gap[k]-gap[g] is $32 \mathrm{~ms}$. The gap length for voiceless plosives is [p]> $[\mathrm{t}]>[\mathrm{k}]>[\mathrm{c}]$. Their voiced plosive partners have the same corresponding order $[\mathrm{b}]>[\mathrm{d}]>[\mathrm{g}]>[\mathrm{J}]$ in terms of their gap values. If the place of articulation of the plosive is located in the front part of the mouth like [p][b], the difference of gap duration between the voiced and voiceless is bigger than those in the backward part of the mouth. All data suggest that velar plosives $[\mathrm{k}]$ and $[\mathrm{g}]$ are special in VOT and gap duration. Their values are greater than that of palatal plosives $[\mathrm{c}]$ and $[\mathrm{J}]$ although their place of articulation is more to the back, and the smallest difference (18ms) between gap and VOT duration also lies in [c] and $[\mathrm{J}]$.

\section{VOT (Voice Onset Time)}

Voice Onset Time (VOT) is the span of time from the release of closure to the start of voicing. In general, voiced plosive sounds will have a VOT that is negative, voiceless unaspirated plosive sounds will have a VOT that is near zero, and voiceless aspirated plosive sounds will have a positive VOT. Indonesian language has four pairs of voiced unaspirated plosives and voiceless unaspirated plosives. One pair of them that does not exist either in English or in Chinese is palatal plosives [c] and [J].

In Figure 3, it can be seen that Indonesian voiced plosives have a longer VOT than voiceless plosives. Voiceless plosives demonstrate an unaspirated property, so their VOT values are very small and nearer to the vertical axis than voiced plosives in the coordinate of sound pattern.

During the research, the unexpected discovery was after ten Javanese informants were recorded, VOTs in Indonesian speech from these Javanese background speakers were hard to be found in spectrograms. This should not be accidental since all ten university informants are from East Java, Central Java and Yogyakarta. Earlier it had been assumed the VOT of voiced plosives could not be found clearly in the spectrograms. It was also once suspected that Indonesian voiced plosives are actually less voiced, because the spectrograms of $[\mathrm{p}]$ and $[\mathrm{b}]$ do not show clear difference on their VOT but on the tiny starting piece of waveform. However, when it was tried again on a few group of students who come from outside Java Island, the negative VOT of voiced plosives evidently appeared on the spectrograms. Their differences in VOT can be illustrated by the following spectrograms of the word besi. 


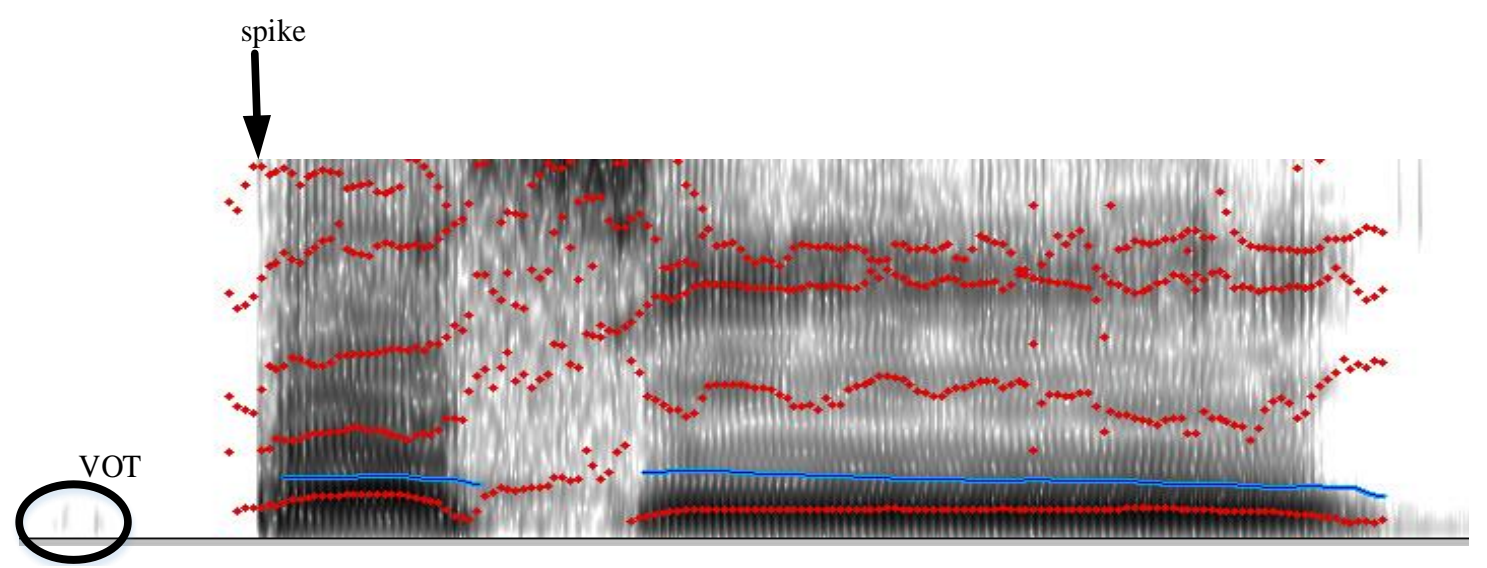

Figure 4. The record of word "besi" pronounced by a speaker with Javanese mother tongue

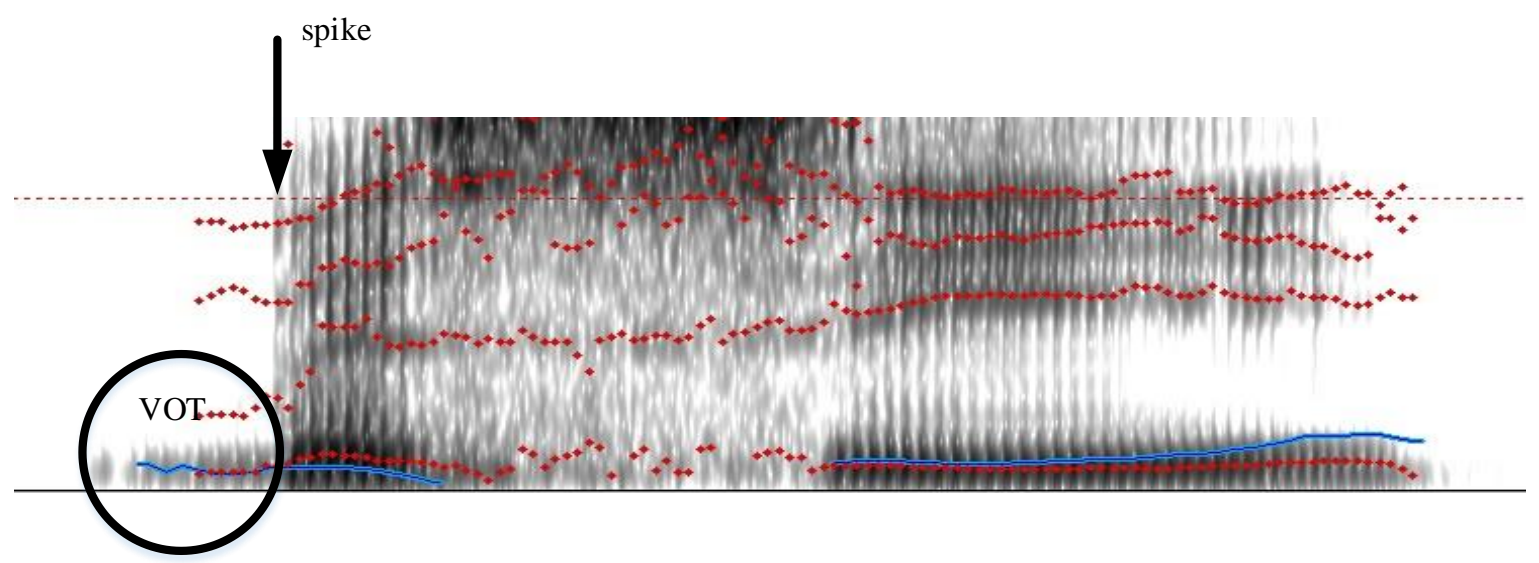

Figure 5. The record of word "besi" pronounced by a speaker with Sasak mother tongue

From the above figures, it can be seen distinctly that there is a small negative VOT in front of the spike in Figure 4. However, Figure 5 shows very clearly a negative VOT in front of the spike. Similar results were obtained in most recordings from members of the two groups. An analysis of the data from the two groups, each with ten members, indicates Javanese speakers do not vibrate their voice cords as obviously as speakers of other languages when pronouncing Indonesian voiced plosives. That is to say, their voicing of voiced plosives is actually unclear. This probably results from the influence of the Javanese language. This feature may also lead to difficulties for non-Javanese listeners in comprehending words with voiced Indonesian plosives spoken by a Javanese speaker. It can be inferred that they would mainly rely on linguistic context to decide the meaning of words with plosives. 


\section{Comparison of Indonesian and Chinese Sound Patterns}

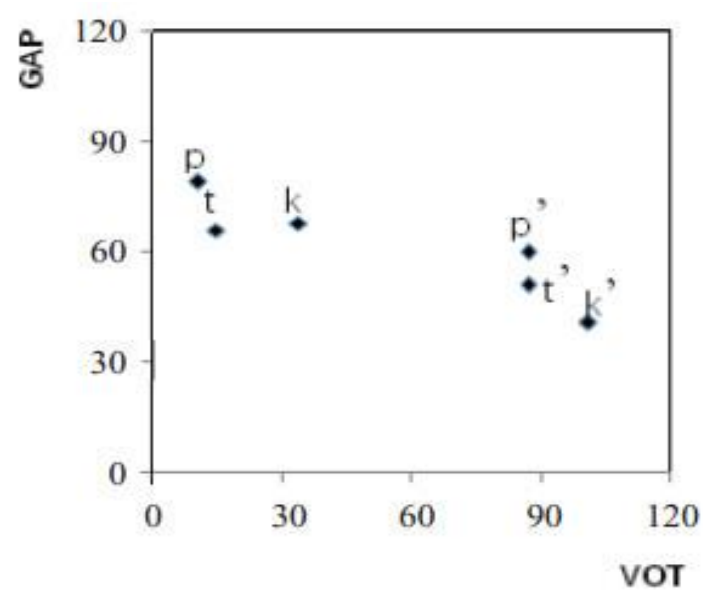

Figure 6. Sound Pattern of Chinese (Shi, 2009)

Based on the charts of sound pattern studies of two languages, the sound patterns of Indonesian plosives and Chinese plosives can be compared to reveal their similarities and differences. A similar characteristic between the two sound patterns of plosives in Indonesian and Chinese is different groups of plosives (voiced and voiceless in Indonesian, aspirated and aspirating in Mandarin Chinese) form separate clusters. Both Indonesian unaspirated voiceless plosives and Chinese unaspirated voiceless plosives tend to have longer gap durations than their respective counterparts. Absolute values of Indonesian voiced unaspirated plosives VOT (around 90ms) are similar to those of Chinese voiceless aspirated plosives VOT, as with Indonesian voiceless unaspirated plosives and Chinese voiceless unaspirated plosives. That is to say, absolute VOT values of Indonesian plosives are almost the same as absolute VOT values of Chinese plosives.

The differences in contrast of plosives between the two languages lead to the very different locations of plosives in the coordinates of sound pattern. Indonesian plosive clusters lie on two sides of the y axis, whereas Mandarin Chinese plosives all lie on the right side of the y axis due to the fact that all Chinese plosives are voiceless. However, gaps of Indonesian unaspirated voiceless plosives are bigger than those of Chinese voiceless unaspirated plosives, and gaps of Indonesian voiced plosives are bigger too than those of Chinese voiceless aspirated plosives. Overall, Indonesian plosives have longer gap durations than Chinese plosives.

\section{DISCUSSION}

From spectrograms of contrasted plosives in the coda of words, it seems that there are differences between voiced and voiceless unreleased stops, but such differences are difficult to detect. This research topic is worthy of further investigation. Furthermore, Indonesian speakers with different regional language background pronounce them differently. There is a tendency for devoicing when voiced plosives appear at the end of a word. Such phenomenon is reflected in people's daily writing. Unreleased voiced stops are often written as their voiceless counterparts, the final voiceless and voiced stops are often mixed up. For instance, lembab 'moist' is often written as lembap, mantap 'great' as mantab and jilid 'cover' is written as jilit. Spellings with such kinds of mistake are often taken as an informal form of the word. Another issue refers to pronunciation of the letter $\langle\mathrm{k}\rangle$ at the end of a syllable because it varies through Indonesia. According to the standardized Indonesian grammar book Tata Bahasa Baku Bahasa Indonesia (Alwi, Dardjowidjojo, Lapoliwa, \& Moeliono, 
2010), when / $\mathrm{k}$ / appears at the syllable final position, it should be pronounced as a glottal stop [?]. In the course of this research, it is found that syllable final $/ \mathrm{k} /$ is realized usually in four ways depending on the language background of informants. If an informant comes from a Javanese language background, the syllable final $/ \mathrm{k} /$ is realized as a glottal stop. For example, the word lapak is pronounced as [lapa?]. If an informant comes from Maluku or Maluku Utara, their realization of $/ \mathrm{k} /$ is unreleased $[\mathrm{k}\urcorner]$. Unreleaseness is expressed with a diacritic $\urcorner$. The word lapak would become [lapak $\urcorner$. Informants from Nusa Tenggara Barat and Nusa Tenggara Timur tend to realize it as an aspirated voiceless $\left[\mathrm{k}^{\mathrm{h}}\right]$, so the word lapak is pronounced as [lapak $\mathrm{k}^{\mathrm{h}}$. Some Sundanese realize $/ \mathrm{k} /$ as a coda of the syllable $\varnothing$. The Indonesian writing system prescribes that there is one letter for one phoneme (Ali, 2000), which explains why the word bakso in the western part of Java Island is often written as baso.

Now let us look at a few striking patterns and think if the letter $\langle\mathrm{k}\rangle$, when appearing as a coda of a syllable, is pronounced as a glottal stop or unreleased $[\mathrm{k}\urcorner]$.

(1) Masak [ma.sa?]/[ma.sak ]

(2) $\operatorname{didik}$ [d,i.di?] / [di.d,ik?]

(3) naik [na.i?] / [na.ik?]

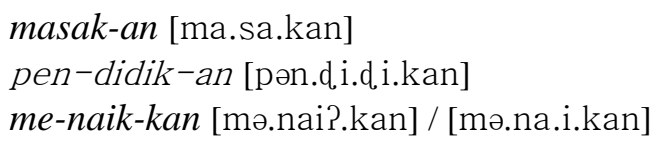

Although the Indonesian official grammar book states that the letter $\langle\mathrm{k}>$ at the coda position is pronounced as a glottal stop, it is still not convincing enough to accept from the perspective of phonology. Similar cases happen to other voiceless plosives that are not audibly released at the end of a syllable.
(4) sambut [sam.but?]
sambutan [sam.bu.tan]
(5) repot [re.pot $\left.{ }^{\urcorner}\right]$ merepotkan [mə.re.pot? ${ }^{\urcorner}$.kan]
(6) harap [ha.rap $\urcorner]$
harapan [ha.ra.pan]

mengharapkan [mən.ha.rap $\urcorner \cdot k a n]$

After unreleased $[\mathrm{t}]$ and $[\mathrm{p}]$ at the end of a syllable experience resyllabification, they become released. For instance, letters $\langle t\rangle$ and $\langle p\rangle$ fill the end of words such as in examples (4), (5) and (6) above. They are attached with new suffixes $\{-a n\}$ and $\{-k a n\}$ like words in examples (1), (2) and (3). This kind of sound change is exactly the same as the pattern in sound [k] of (1) to (3). Judged from the same change in the same pattern, phonologically that $[\mathrm{k}]$ at the end of a syllable is a glottal stop could be denied. Therefore, *masak [ma.sa?], *didik [d.i.dii?], *naik [na.i?].

Based on the above reasoning, it could be concluded that the syllable final $\mathrm{k}$ in Indonesian is actually an unreleased $[\mathrm{k}\urcorner]$. When Van Ophuijsen created a Latin written system for Malay, a diacritic ['] called hamzah at that time was used to stand for a glottal stop. In the course of orthographical development, this symbol is not used anymore in written Indonesian. However, in Indonesian phonology, the glottal stop does exist. They are common in Arabic loanwords such as Jumat [jum. ?.at] and doa [do.?.a]. Also in words when two identical vowels are together in a word, they are not pronounced as a long vowel but two separate vowels with a glottal stop in between. For example, the word saat is pronounced as [sa?at?] , and word cemooh [cə.mo.?.oh].

Another reason that leads to confusion can be tracked back to the modifications of Indonesian spelling. As early as Van Ophuijsen spelling system, the letter $\langle\mathrm{k}\rangle$ was pronounced as [ka] and the diacritic ['] represents a glottal stop. Later this diacritic in some cases was replaced with letter $\langle\mathrm{k}\rangle$. In 1972, the Indonesian Language Congress decided that the diacritic was totally abandoned and all letter k's were pronounced as [k] instead of [?] in order to avoid confusion for Javanese people. This long process of sound standardization and contradictory changes made in it explains why the pronounciation of the letter $\mathrm{k}$ is very controversial and inconsistent. 


\section{CONCLUSION}

The Indonesian plosive pattern displays two clear clusters on the left and right sides of the sound pattern coordinate. The voiceless plosives gaps are longer than the voiced plosives, whereas voiced plosives have much longer VOTs than unaspirated voiceless plosives. However, a comparison of the sequences for voiceless and voiced plosives gaps show the plosive pairs appear in the same order, that is: gap $[\mathrm{p}]>[\mathrm{t}]>[\mathrm{k}]>[\mathrm{c}]$; gap $[\mathrm{b}]>[\mathrm{d}]>[\mathrm{g}]>[\mathrm{f}]$, and $(\operatorname{gap}[\mathrm{p}]-g a p[\mathrm{~b}])>(\operatorname{gap}[\mathrm{t}]-\operatorname{gap}[\mathrm{d}])>(\operatorname{gap}[\mathrm{k}]-\mathrm{gap}[\mathrm{g}])>$ (gap[c]-gap[J]). With a longer gap a speaker uses more force to pronounce it. For the VOT, their length durations can be sequenced as VOT $|[\mathrm{g}]|>|[\mathrm{f}]|>|[\mathrm{d}]|>|[\mathrm{b}]|$ and VOT $[\mathrm{c}]>[\mathrm{k}]>[\mathrm{p}]>[\mathrm{t}]$. From the VOT duration sequences, it can be seen that all Indonesian voiced plosives have longer durations of VOT than voiceless plosives, but differences among members in each group are not large. Theoretically, VOT values of unaspirated voiceless plosives should be very small and close to zero. The results of the data analysis show that the further back in the oral cavity the place of a plosive articulation is, the smaller the VOT absolute value of a plosive is, but its gap value is larger.

This research has verified, using phonetic evidence, that Indonesian speakers with a Javanese background do not vibrate their vocal folds hard enough when pronouncing voiced plosives so that their [p] and [b], [t] and [d], [k] and [g], [c] and [f] are less distinguishable for listeners from other language backgrounds.

Indonesian plosives occur in onset and coda. When in the position of coda, they are usually unreleased. Voiceless plosives are active in both onset and coda due to the fact that the base stratum of Indonesian is Malay. Nevertheless, voiced plosives in the coda can only be found in loanwords. Additionally, the data shows that Indonesian speakers realize syllable final $\mathrm{k}$ in four different ways, $[?],\left[\mathrm{k}^{\urcorner}\right],\left[\mathrm{k}^{\mathrm{h}}\right]$ and $[\varnothing]$, which correspond to their mother tongue influence. This finding is consistent with Indonesian being a second language for many Indonesians.

The sound pattern comparison between Indonesian and Chinese shows that absolute VOT values of Indonesian plosives are almost the same as absolute VOT values of Chinese plosives, and on average Indonesian plosives have longer gap durations than Chinese plosives. This research can be considered as an ontological preliminary research. Further research is needed to build on these findings including areas such as second language perception, articulations and phonological contrast which relate to Chinese learners of Indonesian.

\section{NOTE}

*The authors would like to thank two anonymous reviewers for their helpful comments on the earlier version of this paper.

\section{REFERENCES}

Ali, L. (2000). Sejarah Ejaan Bahasa Indonesia. Jakarta: Pusat Bahasa Departemen Pendidikan Nasional.

Alwi, H., Dardjowidjojo, S., Lapoliwa, H., \& Moeliono, A. M. (Eds.). (2010). Tata Bahasa Baku Bahasa Indonesia (Ketiga). Jakarta: Balai Pustaka.

Chaer, A. (2009). Fonologi Bahasa Indonesia. Jakarta: Penerbit Rineka CiptaChomsky, N., \& Halle, M. (1968). The Sound Pattern of English. New York: Harper\& Row.

Ladefoged, P., \& Johnson, K. (2006). A Course in Phonetics (7th ed.). Stamford: Cengage Learning.

Lapoliwa, H. (1981). A Generative Approach to the Phonology of Bahasa Indonesia. Canberra: Department of Linguistics, Research School of Pacific Studies, The Australian National University. 
Liang, Y. (2014). Comparison Study of Indonesian and Chinese Phonemics. Hunan Normal University. Retrieved from http://www.cnki.net/kcms/detail/Detail.aspx?dbname=CMFD201402\&filename=101423627 5.nh\&v=\&filetitle=印尼语与汉语语音对比研究 10/09/2016Muslich, M. (2008). Fonologi Bahasa Indonesia. Jakarta: PT Bumi Aksara.

Ohala, J. J., \& Jaeger, J. J. (Eds.). (1986). Experimental Phonology. Orlando: Academic Press, Inc.

Shi, F. (2008). 语音格局 Sound Pattern. Beijing: The Commercial Press.

Shi, F. (2009). 实验音系学探索 Exploration of Experimental Phonology. Beijing: Peking University Press.

Shi, F. (2012). 语音平面实验录 Experiments of Phonetic Level. Beijing: Beijing Language and Culture University Press.

Shi, F. (2013). 语调格局 Sound Pattern of Intonation. Beijing: Beijing Language and Culture University Press.

Zhu, G. (2008). Bahasa Indonesia Kuliah Intensif Tingkat Dasar. Guangzhou: World Book Publisher. 